\title{
FORMULASI STRATEGI KORPORASI DALAM KETIDAKPASTIAN MASA DEPAN PASCA COVID-19
}

\author{
Edon Ramdani \\ Universitas Pamulang
}

Email: edon_ramdani@yahoo.com

\begin{abstract}
The Covid-19 virus which has swept the world and become a global pademic has changed the world order. The reduced social economic activities of the community to reduce social interaction that can accelerate the spread of the virus, resulting in a decline in the performance of economic sectors. Many industries experience a decline in revenue and can result in further cessation of company operations. Pademi Covid-19 to date has not been able to predict how long it will end which causes uncertainty about the future. In order for a company to continue to exist and grow sustainably, it is very important to formulate a future strategy that is full of uncertainty. In this article, we review strategies options that can be applied to various levels of uncertainty. In the future uncertainty, the leadership of the company is demanded to be more courageous in making strategic decisions. From a variety of alternative strategy choices, in order to deal with the difficult conditions at the moment, the initial theory regarding investment management can be considered in the form of a business diversification strategy. So that the risks experienced can be spread in various fields of business / industry not only in one business, as the theory of the father of investment management Herry Markowizt "don't put all your eggs in one basket".
\end{abstract}

Keywords : Covid-19, World Order, Uncertainty, Strategy, Diversification

\section{PENDAHULUAN}

Sejak kemunculan awalnya di Provinsi Wuhan, China pada akhir tahun 2019 yang lalu Virus Corona Baru atau lebih dikenal dengan Covid-19 kini telah menyebar kepenjuru dunia dengan lebih dari lima juta penduduk dunia terjakiti dan tingkat kematian lebih dari tiga ratus ribu jiwa, termasuk Indonesia dengan lebih dari 26.000 orang terjangkit dengan tingkat kematian lebih dari 1.500 orang. Penyakit Covid-19 mudah menular dan menginfeksi seseorang terlebih jika ia kontak langsung dengan penderita tanpa alat pelindung diri yang memadai, artinya virus ini akan mudah menyebar jika jarak antar orang tidak dibatasi. Untuk itu kemudian banyak negara melakukan kebijakan pembatasan kegiatan sosial demi menghindari penyebaran yang lebih luas. Akibat pembatasan kegiatan sosial yang dilakukan menyebabkan berkurangnya aktifitas ekonomi, masyarakat menjadi lebih memprioritaskan kebutuhan pokok (primer) dan kesehatan terlebih dahulu, sementara untuk kebutuhan sekunder dan tersier menjadi pilihan berikutnya.

Banyak sektor industri mengalami penurunan kinerja sejak virus corona mewabah, berdasarkan laporan keuangan perusahaan yang terdaftar di Bursa Efek Indonesia sektor industri seperti properti mengalami penurunan laba bersih - 12,9\% selama kuartal pertama tahun 2020 , begitu juga dengan otomotif dan media $-34,4 \%$ bahkan untuk sektor pariwisata dan perhotelan mengalami penurunan hingga $-1.934,3 \%$. Sementara disektor industri lain seperti barang konsumsi dan farmasi mengalami pertumbuhan $13,3 \%$, perdagangan $44,5 \%$ bahkan sektor agrikultur tumbuh $136,2 \%$.

Virus corona baru hingga saat ini belum dapat diprediksi hingga kapan akan berakhir demikian juga dengan obat/vaksin untuk mengobatinya sampai saat ini masih dalam tahap pengembangan dan belum juga ditemukan. Hal ini membuat ketidakpastian dimasa depan, kalaupun vaksin sudah tersedia dunia masih dilanda ketidakpastian juga dengan perkembangan atau mutasi dari virus corona baru ini. Ketidakpastian masa depan ini harus diantisipasi dengan baik oleh para pemangku kepentingan, bagi pemilik maupun manajemen perusahaan terutama 
yang sektor industri usahanya mengalami penurunan tentu harus dianalisis strategi yang tepat diterapkan agar perusahaan dapat terus eksis dimasa depan. Apakah perusahaan tetap fokus dengan sektor industri yang digelutinya saat ini atau memasuki bidang industri lain. Jenis ketidakpastian tentang fakta, angka, dan sains ini disebut ketidakpastian epistemik. Hal ini disebabkan oleh kurangnya pengetahuan tentang masa lalu dan masa kini. Akan sangat sulit untuk memprediksi masa depan dalam situasi yang penuh ketidakpastian. Ketidakpastian seperti saat ini membuat banyak perusahaan kesulitan, sehingga perlu meninjau dan merumuskan kembali rencana strategisnya. Namun proses tradisional perencanaan strategi tidak akan banyak membantu. Proses tradisional mengasumsikan masa depan bisa diprediksi, paling tidak sebagian besarnya. Proses tradisional juga mengarahkan eksekutif untuk melihat ketidakpastian secara biner - dunia itu pasti, dan karena itu terbuka untuk prediksi yang tepat tentang masa depan, atau tidak pasti, karena itu sama sekali tidak dapat diprediksi, Ningky Sasanti Munir (2020).

Suatu perusahaan didirikan untuk mencapai sesuatu (keuntungan dan keberlangsungan hidup), seiring berjalannya waktu, misi dan visi perusahaan dapat berubah menyesuaikan dengan kondisi lingkungan eksternal yang dihadapi dan maupun daya dukung lingkungan internalnya. Penyesuaian tersebut perlu dilakukan untuk memanfaatkan peluang baru atau merespon kondisi terkini. Virus corona baru telah merubah tatanan dunia baik disektor ekonomi, industri dan sektor-sektor lainnya. Dalam kondisi ini setiap perusahaan dituntut untuk kembali memformulasikan strateginya agar dapat terus bersaing dan bertahan ditengah ketidakpastian masa depan. Pada penelitian ini penulis mencoba mengulas kembali berbagai alternatif strategi dan bagaimana top eksekutif atau pimpinan perusahaan sebaiknya memformulasikan kembali strateginya ditengah ketidakpastian masa dengan yang salah satunya disebabkan oleh pademi virus Covid-19 yang tengah melanda dunia dan belum dapat dipastikan kapan akan berakhir.

\section{Penelitian Terdahulu}

Penelitian pertama, yang dilakukan oleh Pasi Heikkurinen (2018) mengenai, "Strategic corporate responsibility: a theory review and synthesis", mengemukakan bahwa perusahaan bertanggung jawab atas strateginya dengan memformulasikan ulang strategi tersebut dalam perspektif persaingan terkini melalui sudut pandang strategi klasik.

Penelitian kedua, João Ferreira, Jens Mueller and Armando Papa (2018) dalam penelitiannya mengenai, "Strategic knowledge management: theory, practice and future challenges", mengemukakan Ekonomi pengetahuan saat ini mengharuskan perusahaan untuk membuat struktur bisnis baru dan konsep baru untuk pengelolaan sumber dayanya agar tetap kompetitif. Yang terbaru pendekatan manajemen strategis cenderung mempertimbangkan strategis aliansi (sebagai sumber pengetahuan) dan modal intelektual (manusia, struktural dan relasional modal) sebagai sumber utama untuk keunggulan kompetitif yang berkelanjutan

Penelitian ketiga, Vanessa Pires and Guilherme Trez (2017) dalam penelitiannya mengenai, "Corporate reputation A discussion on construct definition and measurement and its relation to performance", mengemukakan bahwa berbagai pendekatan yang berbeda dari konstruksi perusahaan, dalam hal ini mengidentifikasi definisi yang komprehensif yang dapat dioperasionalkan untuk keperluan pengukuran. Reputasi perusahaan diakui sebagai istilah yang beragam, dengan makna yang berbeda untuk disiplin ilmu dan perspektif yang berbeda. Untuk strategi penulis, strategi korporasi dapat dilihat sebagai sumber daya yang menghasilkan keuntungan kompetitif.

Penelitian keempat, Olivier Furrer, J. Rajendran Pandian dan Howard Thomas (2007) mengenai, "Corporate strategy and shareholder value during decline and turnaround", mengemukakan bahwa selama tindakan yang diambil oleh manajemen meningkatkan efisiensi, tindakan seperti itu harus memiliki dampak positif pada nilai pemegang saham. Jika suatu perusahaan terus beroperasi secara tidak efisien di bidang manufaktur dan pemasaran, maka perusahaan tersebut tidak dapat kembali ke keadaan semula dan oleh karena itu 
investormenimbang variabel-variabel strategi ini sangat dibandingkan dengan piutang dagang dan hutang dagang.

Kemudian penelitian kelima sebagai sumber literatur pada penelitian ini adalah penelitian yang dilakukan oleh Maganjo Peter Muriuk dan Kavale Stanley (2015) mengenai," Determinants of Strategic Plan Implementation in Organizations: A Case Study of Chai Trading Company Limited", mengemukakan dari hasil penelitiannya bahwa implementasi rencana strategis tergantung pada Strategis Manajemen Sumber Daya Manusia( SHRM), daya saing strategis, budaya organisasi dan kepemimpinan perusahaan. Setiap variabel ditemukan memiliki pengaruh yang signifikan terhadap implementasi rencana strategis. Oleh karena itu, peneliti merekomendasikan lebih banyak upaya dalam perencanaan tenaga kerja untuk memelihara sumber daya manusia strategis yang menghasilkan keunggulan kompetitif yang lebih baik.

\section{METODE}

Penelitian ini menggunakan metode kualitatif deskriftif dengan sumber datanya adalah data sekunder yang didapat dari jurnal-jurnal internasional maupun nasional dan juga dari ulasan-ulasan para pakar manajemen strategis dan pelaku bisnis. Pada penelitian ini analisis dilakukan dengan menitikberatkan mengenai teori-teori strategi dan pilihan strategi yang dapat mungkin dapat diterapkan pada kondisi masa depan yang penuh dengan ketidakpastian terutama akibat dari wabah Covid-19 yang tengah melanda dunia saat ini.

Kerangka analisis dalam penelitian ini dimulai dari analisis pertumbuhan industri ditengah mewabahnya virus Covid-19, kemudian mendeskripsikan kembali teori-teori manajemen strategi dan selanjutnya dilakukan analisis terhadap kemungkian strategi yang layak diterapkan oleh suatu perusahaan agar tetap dapat bersaing dan tumbuh dalam ketidakpastian masa depan

\section{HASIL DAN PEMBAHASAN}

\section{Alternatif Strategi}

Strategi-strategi alternatif yang dapat dijalankan suatu perusahaan dikelompokan menjadi beberapa tindakan strategi seperti: integrasi kedepan, integrasi kebelakang, integerasi horizontal, peneterasi pasar, pengembangan pasar, pengembangan produk, diversifikasi terkait, diversifikasi tidak terkait, penciutan/pengurangan, divestasi, dan likuidasi.

"Perencanaan strategis melibatkan pilihan-pilihan yang menempatkan sumber daya dalam risiko" dan trade-off yang mengorbankan peluang" (Hansen and Smith. 2003).

Organisasi tidak dapat melakukan banyak hal dengan baik karena sumber daya dan talenta tersebar secara tipis dan pesaing memperoleh atau memiliki keunggulan. Di perusahaanperusahaan yang sangat terdiversifikasi, strategi gabungan biasanya dijalankan ketika divisi yang berbeda menjalankan strategi yang juga berbeda. Selain itu, organisasi yang sedang berjuang untuk bertahan hidup bisa secara bersamaan menjalankan gabungan beberapa strategi defensif, seperti divestasi, likuidasi, dan penciutan.

\section{Strategi-strategi Integrasi}

Integrasi ke depan, integrasi ke belakang, dan integrasi horisontal secara kolektif kadang disebut sebagai strategi-strategi integrasi vertikal (vertical integration). Strategi-strategi integrasi vertikal memungkinkan suatu perusahaan memperoleh kendali atas distributor, pemasok, dan/atau pesaing.

\section{Integrasi Ke Depan}

Integrasi ke depan (forward integration) berkaitan dengan usaha untuk memperoleh kepemilikan atau kendali yang lebih besar atas distributor atau peritel. Tujuan dari integrasi ke depan adalah menangani secara langsung distribusi produk perusahaan kepada konsumen tanpa 
melalui pihak ketiga atau menguasai secara mayoritas kendali dari distribusi. Beberapa pedoman ketika integrasi ke depan menjadi suatu strategi yang sangat efektif:

1. Ketika distributor perusahaan yang ada saat ini tidak kompetitif, menjadi mahal dan tidak dapat diandalkan.

2. Ketika ketersediaan distributor yang berkualitas menjadi sangat terbatas.

3. Ketika suatu perusahaan berkompetisi dalam industri yang tengah tumbuh dan diprediksi akan terus berkembang pesat.

4. Ketika suatu perusahaan memiliki sumber daya modal maupun manusia yang dapat digunakan untuk pendistribusian produk-produknya sendiri.

5. Ketika keuntungan dari produksi sangat baik dan ini menjadi pertimbangan perusahaan untuk memprediksi permintaan dari produknya melalui integrasi ke depan.

6. Ketika distributor yang ada saat ini menikmati laba yang tinggi, hal ini membuat perusahaan untuk melakukan usaha distribusinya sendiri dengan harapan margin laba yang tinggi tersebut.

\section{Integrasi Ke Belakang}

Integrasi ke belakang (backward integration) adalah suatu upaya/strategi untuk memiliki atau mengendalikan lebih besar atas pemasok perusahaan. Strategi ini sangat tepat dijalankan ketika pemasok perusahaan yang ada saat ini tidak bisa diandalkan, terlampau mahal, atau tidak mampu memenuhi kebutuhan perusahaan. Tujuh pedoman tentang kapan integrasi kebelakang menjadi pilihan strategi yang efektif:

1. Ketika pemasok perusahaan saat ini menjadi sangat mahal dan tidak kompetitif.

2. Ketika jumlah pesaing banyak sementara pemasok yang dibutuhkan terbatas.

3. Ketika industri bersaing ditengah industri yang sedang berkembang pesat.

4. Ketika perusahaan memiliki sumber daya modal maupun manusia yang mampu digunakan untuk mengelola pemasokan bahan mentahnya sendiri

5. Ketika keuntungan dari harga yang stabil sangat tinggi.

6. Ketika bisnis pemasok sangat aktraktif dan memiliki laba yang tinggi, sehingga menarik minat perusahaan untuk memasuki bisnis tersebut.

7. Ketika perusahaan perlu mengakusisi atau memperoleh sumber daya yang dibutuhkan secara tepat.

\section{Integrasi Horisontal}

Integrasi horisontal (horizontal integration) mengacu pada strategi yang mengupayakan kepemilikan atas kendali yang lebih besar atas pesaing perusahaan. Merger, Akuisisi, dan pengambilalihan (take over) diantara para pesaing memungkinkan peningkatan skala ekonomi serta mendorong transfer sumber daya dan kompentensi. Lima pedoman tentang kapan integrasi horisontal menjadi suatu strategi yang efektif:

1. Ketika perusahaan dapat memperoleh karakteristik monopolistik disuatu wilayah atau kawasan tertentu tanpa bertentangan dengan aturan pemerintah yang melarang "penguasaaan substansial" untuk menghambat persaingan.

2. Ketika organisasi bersaing di industri yang sedang berkembang.

3. Ketika meningkatnya skala ekonomi memberikan keunggulan kompetitif yang besar.

4. Ketika sumber daya modal dan manusia yang dimiliki dapat digunakan untuk melakukan ekspansi usaha.

5. Ketika pesaing melemah karena kurangnya keterampilan manajerial atau kebutuhan akan sumber daya tertentu yang dimiliki suatu perusahaan.

\section{Strategi-strategi Intensif}

Penetrasi pasar, pengembangan pasar, dan pengembangan produk kadang disebut sebagai strategi intensif (intensive strategies) sebab hal tersebut mengharuskan adanya upaya intensif dari perusahaan jika posisi kompetitif sebuah perusahan dengan produk yang ada saat ini ingin membaik. 


\section{Penetrasi Pasar}

Penetrasi pasar (market penetration) adalah strategi yang mengusahakan peningkatan pangsa pasar untuk produk atau jasa yang ada di pasar saat ini melalui upaya-upaya pemasaran yang lebih besar. Penetrasi pasar meliputi penambahan tenaga penjualan, peningkatan aktifitas iklan, penawaran produk secara intensif, atau melakukan upaya pemasaran yang lebih besar (berlipat). beberapa pedoman tentang kapan penetrasi pasar menjadi strategi yang efektif:

1. Ketika pasar saat ini belum jenuh dengan produk atau jasa tertentu.

2. Ketika tingkat pemakaian konsumen saat ini dapat dinaikkan secara signifikan.

3. Ketika pangsa pasar pesaing utama menurun, sementara total penjualan industri meningkat.

4. ketika meningkatnya skala ekonomi memberikan keunggulan kompetitif yang besar.

\section{Pengembangan Pasar}

Pengembangan pasar (market development) meliputi pengenalan produk atau jasa yang ada saat ini ke wilayah-wilayah geografis yang baru. Beberapa pedoman tentang kapan pengembangan pasar menjadi strategi yang efektif diantaranya:

1. Ketika saluran-saluran distribusi baru yang tersedia dapat diandalkan, tidak mahal dan kualitasnya baik.

2. Ketika perusahaan sangat berhasil dalam bisnis yag dijalankannya.

3. Ketika tumbuhnya pasar-pasar baru yang belum digarap/dikembangkan.

4. Ketika perusahaan memiliki sumber daya modal dan manusia yang dapat digunakan untuk mengelola perluasan operasi.

5. Ketika perusahaan memiliki kapasitas produksi yang berlebih.

6. Ketika industri dasar perusahaan berkembang dengan cepat dan menjadi global cakupannya.

\section{Pengembangan produk}

Pengembangan produk (product development) adalah suatu strategi yang mengupayakan peningkatan dengan cara memperbaiki atau memodifikasi produk dan jasa saat ini. Dalam pengembangan produk sebaiknya menghasilkan produk yang memberikan nilai tambah bagi konsumen dan telah mengikuti presepsi/selera konsumen. Lima pedoman tentang kapan pengembangan produk dapat menjadi strategi yang efektif:

1. Ketika perusahaan memiliki produk-produk yang berhasil dan berada pada tahap kematangan dari tahap siklus produk.

2. Ketika perusahaan bersaing di industri yang memiliki perkembangan teknologi yang cepat.

3. Ketika pesaing mampu menawarkan produk yang lebih berkualitas dengan harga yang kompetitif.

4. Ketika perusahaan bersaing dalam industri dengan tingkat pertumbuhan yang tinggi.

5. Ketika perusahaan memiliki kapabilitas penelitian dan pengembangan $(R \& D)$ yang sangat kuat.

\section{Strategi Diversifikasi}

Terdapat dua jenis strategi diversifikasi, yaitu: diversifikasi terkait (related diversification) dan diversifikasi tak terkait (unrelated diversification). Bisnis dikatakan terkait ketika memiliki kesesuaian rantai nilai yang strategis dan lintas bisnis sehingga bernilai secara kompetitif. Sementara bisnis dikatakan tidak terkait ketika rantai nilai bisnis sangat tidak mirip sehingga tidak terdapat hubungan lintas bisnis yang bernilai kompetitif. Perusahaan ketika memutuskan untuk melakukan diversifikasi terkait, dengan pertimbangan-pertimbangan sebagai berikut:

1. Transfer keahlian yang bernilai kompetitif dibidang teknologi dan kapabilitas lainnya dari satu bisnis ke bisnis yang lain.

2. Menyatukan aktivitas-aktivitas antar bisnis yang terpisah kedalam satu operasi tunggal untuk mendapatkan biaya yang lebih murah.

3. Memanfaatkan merek dagang perusahaan yang sudah sangat dikenal luas. 
4. Kerja sama lintas bisnis untuk menghasilkan kekuatan dan kapabilitas sumber daya yang kompetitif.

Strategi diversifikasi menjadi tidak terlalu disukai manakala organisasi mendapati bahwa mengelola berbagai aktivitas bisnis yang beragam tidaklah mudah. Sementara jika perusahaan hanya tergantung/menjalani satu bisnis tunggal saja maka resiko yang dihadapi tidaklah sedikit, perkembangan teknologi baru, produk baru atau perubahan prefensi pembeli dapat memperlemah suatu industri tertentu. Sebagai contoh; perkembangan teknologi telpon seluler secara permanen telah mengubah industri saluran telpon jarak jauh.

Penerapan strategi diversifikasi harus lebih dari sekedar menyebarkan resiko bisnis keberagam industri, karena para pemegang saham dapat melakukan hal ini dengan membeli saham dari perusahaan-perusahaan yang berbeda atau dengan melakukan investasi pada reksa dana. Dengan demikian industri yang dipilih unntuk diversifikasi harus cukup menarik untuk menghasilkan pengembalian investasi yang konsisten dan menawarkan potensi lintas divisi operasi untuk mendapatkan sinergi yang lebih besar daripada yang dapat dicapai dengan sendirisendiri. Diversifikasi dapat digunakan perusahaan sebagai salah satu pilihan strategi untuk mengembangkan bisnisnya. Strategi diversifikasi banyak digunakan manajemen untuk meningkatkan kinerja perusahaan. Selanjutnya pengertian akan diversifikasi akan dijelaskan sebagai berikut:

\section{Pengertian Diversifikasi}

Menurut Pawaskar (1999), diversifikasi suatu perusahaan, baik dengan ekspansi internal atau eksternal, intinya merupakan suatu pertumbuhan perusahaan. Pendapat lain menurut Pawaskar (1999), perusahaan yang diversifikasi dapat dikatakan perusahaan yang memiliki operasi lebih dari satu industri.

\section{Alasan Diversifikasi}

Selama bisnis yang digeluti perusahaan mampu menghasilkan keuntungan yang baik dan mampu meningkatkan nilai perusahaan, tidak ada alasan yang mendesak untuk melakukan diversifikasi. Namun menjalankan bisnis tunggal bukanlah tanpa resiko. Ketika kemajuan teknologi mampu menciptakan produk alternatif, beralihnya presepsi konsumen, industri yang sangat kompetitif akan menjadi tidak aktraktif dan menguntungkan, maka prospek pertumbuhan perusahaan akan melemah. Kondisi tersebut menjadi pertimbangan bagi manajemen untuk melakukan ekspansi ke bisnis lain, dengan tujuan untuk menyebar dan mengurangi risiko kerugian. Alasan lain ketika perusahaan melakukan strategi diversifikasi, diantaranya:

1. Ketika adanya peluang untuk melakukan ekspansi ke dalam industri yang memiliki teknologi dan produk yang saling melengkapi dengan bisnis yang ada sekarang.

2. Ketika dapat menyebarkan kompetensi dan kapabilitas yang dimiliki dengan melakukan ekspansi ke dalam bisnis dimana ada kesamaan sumber daya yang merupakan faktor kesuksesan dan aset kompetitif yang berharga berharga.

3. Ketika diversifikasi ke dalam industri terkait yang dapat mengurangi biaya.

4. Ketika kekuatan nama (merek) yang diketahui secara luas dapat digunakan untuk produk dari bisnis lain dan mampu meningkatkan penjualan dan keuntungan bagi bisnis tersebut.

\section{Diversifikasi Terkait}

Diversifikasi terkait, dilakukan manakala perusahaan mengembangkan bisnisnya dengan memasuki industri baru yang memiliki kecocokan strategi dan kesamaan rantai nilai (value chain). Kesamaan rantai nilai ini memungkinkan perusahaan menjalankan usahanya dengan efektif. Suatu perusahaan ketika melakukan diversifikasi terkait, dengan pertimbangan sebagai berikut:

1. Ketika perusahaan berkompetisi di industri yang tidak mengalami pertumbuhan.

2. Ketika akan menambah produk baru, namun produk baru tersebut terkait erat untuk mendorong penjualan produk saat ini. 
3. Ketika pengembangan produk baru dapat dilakukan dengan harga yang kompetitif dan dapat bersaing.

4. Ketika pengembangan produk baru memiliki kaitan erat dengan tingkat penjualan produk saat ini.

5. Ketika manajemen memiliki organisasi yang kuat.

\section{Kriteria Diversifikasi Terkait}

Strategi diversifikasi terkait meliputi membangun perusahaan kedalam bisnis yang rantai nilainya memiliki kecocokan strategis kompetitif berharga/bernilai. Kecocokan strategi terjadi setiap kali ada satu atau lebih kegiatan yang terdiri dari rantai nilai bisnis yang berbeda namun cukup mirip dengan kegiatan yang ada sekarang, yaitu;

1. Mentransfer keahlian kompetitif berharga, teknologi know-how, atau kemampuan lainnya dari satu bisnis ke bisnis lainnya.

2. Menggabungkan kegiatan rantai nilai terkait bisnis yang terpisah ke dalam satu operasi untuk mencapai biaya yang lebih rendah.

3. Memanfaatkan penggunaan umum dari nama merek terkenal dan kuat.

4. Kolaborasi lintas bisnis untuk menciptakan kekuatan sumber daya yang kompetitif, berharga dan memiliki kemampuan.

Kolaborasi kecocokan strategi lintas bisnis dapat terjadi disetiap lini dari rantai nilai: pada penelitian dan pengembangan $(R \& D)$, aktivitas teknologi, pada aktivitas rantai nilai dan kerjasama dengan pemasok, pada manufacturing, penjualan dan pemasaran, pada aktivitas distribusi atau pada aktivitas administrasi.

\section{Kebijakan Eksekutif Dalam Pengambilan Keputusan}

Dalam pengambilan keputusan sering kali dipengaruhi oleh keyakinan dan keberanian seseorang untuk menentukan langkah-langkah kedepan. Demikian pula yang dilakukan oleh para pimpinan perusahaan. Pada kelompok eksekutif yang yakin bahwa dunia ini sama sekali tidak dapat diprediksi, proses berpikir yang sistematis dan analitis cenderung dihilangkan dalam proses perencanaan. Keputusan strategis sering kali dibuat berdasarkan naluri yang terbentuk oleh pengalaman masa lalu. Namun sebaliknya bagi para eksekutif yang tidak mau mengambil risiko, tidak percaya pada naluri mereka, bingung, dan menderita kelumpuhan keputusan. Para eksekutif dalam kelompok ini cenderung menghindari membuat keputusan strategis tentang produk, pasar, dan teknologi yang harus dikembangkan. Mereka lebih fokus pada reenginering, manajemen kualitas, atau program pengurangan biaya internal. Meski berharga, programprogram itu bukan pengganti strategi. Kemudian bagaimana sebaiknya para eksekutif menghadapi ketidakpastian besar dalam menyusun kembali rencana strategisnya, bila asumsiasumsi dasar yang selama ini digunakan ternyata banyak yang tidak berlaku.

\section{Tingkat Ketidakpastian}

Kata ketidakpastian berarti suatu keraguan, dan dengan demikian pengertian ketidak pastian dalam arti yang luas adalah suatu pengukuran dimana validitas dan ketepatan hasilnya masih diragukan, terdapat empat tingkatan ketidakpastian:

1. Tingkat satu, eksekutif dapat memprediksi masa depan sebagai basis pengembangan strategi bisnis perusahaannya. Variabel-variabel yang dibutuhkan untuk mengembangkan strategi tampak cukup jelas dan perilakunya pun diyakini dapat diprediksi.

2. Tingkat dua, masa depan dapat digambarkan sebagai salah satu dari beberapa alternatif, atau skenario diskrit. Analisis lingkungan eksternal tidak dapat mengidentifikasi dengan meyakinkan skenario mana yang akan terjadi, namun tetap dapat membantu membangun probabilitas. Ketidakpastian tingkat 2 ini cukup sering dialami oleh perusahaan, terutama yang berada dalam situasi persaingan yang memiliki intensitas tinggi dengan pesaing-pesaing agresif. Ketidakpastian muncul karena masing-masing perusahaan harus memprediksi strategi lawan dan bersiap melakukan serangan balik, atau membangun pertahanan yang diyakini akan sulit digempur lawan. 
3. Tingkat tiga, berbagai potensi masa depan dapat diidentifikasi, namun sulit membangun skenario karena variabel-variable kunci yang diperlukan hanya sedikit yang bisa dipegang. Pengalaman masa lalu bukannya membantu, justru bisa menjatuhkan karena perilaku viariabel kunci, seperti preferensi konsumen, teknologi baru, produk baru, kelompok konsumen baru, dan lain sebagainya tidak dikenal. Situasi ini banyak dialami oleh perusahaan yang melakukan ekspansi bisnis dengan melakukan ekspansi ke berbagai negara yang kurang dikenal perilaku pasarnya, melakukan jointventure dengan perusahaan lain, melakukan akuisisi perusahaan lain untuk memperoleh kompetensi yang mungkin diperlukan, atau mengembangkan teknologi yang belum tentu akan dibutuhkan di masa depan.

4. Kemudian terakhir ketidakpstian tingkat empat, berbagai dimensi ketidakpastian berinteraksi untuk menciptakan lingkungan yang hampir mustahil untuk diprediksi. Tidak seperti dalam situasi tingkat 3, kisaran hasil potensial tidak dapat diidentifikasi, apalagi skenario dalam rentang tersebut. Bahkan diyakini tidak mungkin untuk mengidentifikasi, apalagi memprediksi, semua variabel yang relevan yang akan menentukan masa depan. Ketidakpastian tingkat 4 ini sangat jarang, dan biasanya hanya terjadi sebentar karena kemudian beralih menjadi tingkat 3 bahkan tingkat 2. Namun demikian, kenyataannya saat ini dengan pademi Covid-19, situasi ketidakpastian tingkat 4 ini ada dan sudah lewat lima bulan belum juga menunjukkan tanda-tanda akan bergerak ke tingkat 3 . Baik pada ketidakpastian tingkat 3 maupun 4, perusahaan perlu mengembangkan skenario sejauh informasi yang dimiliki. Karena tidak ada skenario diskrit alami di tingkat 3 , memutuskan alternatif skenario mana yang mungkin dikembangkan sebagian besar membutuhkan seni.

Namun ada beberapa aturan umum. Pertama, kembangkan sejumlah kecil alternatif skenario, kemudian lakukan evaluasi pada lebih dari empat skenario akan sangat sulit dilakukan. Kedua, hindari mengembangkan skenario yang tidak memiliki implikasi unik untuk pengambilan keputusan strategis; pastikan setiap skenario menawarkan gambaran yang berbeda tentang struktur, perilaku, dan kinerja industri. Ketiga, kembangkan serangkaian skenario yang secara kolektif memperhitungkan kisaran kemungkinan (probable) hasil di masa depan.

Pengembangan dan analisis skenario di tingkat 4 lebih kualitatif dibandingkan hal yang sama di tingkat 3 . Namun ini lebih baik dibandingkan bertindak hanya berdasarkan naluri semata. Upaya mengembangkan skenario merupakan upaya para eksekutif untuk memahami secara sistematis apa yang diketahui dan apa yang mungkin diketahui. Eksekutif harus dapat mengidentifikasi informasi apa yang dipercaya tentang masa depan untuk menjadi basis perencanaan strategis ke depan. Pemahaman mengenai karakteristik dan perilaku pasar di awal perubahan tingkat ketidakpastian akan membantu memilah apakah kepercayaan seperti itu realistis atau tidak. Ini merupakan perspektif strategis yang sangat berharga dalam proses pengembangan strategi.

\section{Postur Strategis}

Setelah memahami tingkat ketidakpastian dan mengembangkan skenario, perusahaan perlu menetapkan postur strategis. Pada dasarnya, postur mendefinisikan tujuan (intent) strategi relatif terhadap keadaan industri saat ini dan masa depan. Ada tiga postur strategis yang dapat dipilih perusahaan untuk menghadapi ketidakpastian: membentuk (shaping), mengadaptasi (adapting), atau "memesan hak untuk bermain" (reserving). Shaper atau membentuk (masa depan) bertujuan untuk mengarahkan industri dimana perusahaan beroperasi kearah struktur baru sesuai rancangan mereka sendiri. Strategi mereka adalah tentang menciptakan peluang baru di pasar, baik dengan mengguncang industri yang relatif stabil atau dengan mencoba mengendalikan arah pasar dalam industri dengan tingkat ketidakpastian yang tinggi. Gojek, misalnya, sadar atau tidak telah berperan sebagai shaper dengan membentuk perilaku baru konsumen dan industrinya.

Adaptor adalah postur strategis di mana perusahaan menetapkan struktur industri saat ini dan evolusi di masa depan sebagai kondisi normal (the new normal), dan mereka bereaksi 
(beradaptasi) terhadap peluang yang ada, sekecil apapun peluang tersebut. Dalam lingkungan dengan sedikit ketidakpastian, memilih pemposisian strategis, yaitu dimana dan bagaimana bersaing dalam industri saat ini. Pada tingkat ketidakpastian yang lebih tinggi, strategi mereka didasarkan pada kemampuan untuk mengenali dan merespons dengan cepat perkembangan pasar.

Postur strategis ketiga, reserver, mirip dengan adaptasi namun lebih berorientasi pada keunggulan yang sudah dimiliki dan perbaikan internal perusahaan. Postur ini hanya relevan pada tingkat 2 hingga 4 . Pilihan postur ini melibatkan investasi tambahan yang menempatkan perusahaan pada posisi istimewa, baik melalui informasi superior, struktur biaya, atau hubungan antara pelanggan dan pemasok. Itu memungkinkan perusahaan untuk menunggu sampai lingkungan menjadi lebih pasti sebelum merumuskan strategi.

\section{Aksi Strategis}

Postur bukanlah strategi yang lengkap. Postur mengklarifikasi tujuan strategis tetapi bukan aksi atau tindakan yang diperlukan untuk memenuhi maksud itu. Tiga jenis aksi sangat relevan untuk menerapkan strategi dalam kondisi ketidakpastian: taruhan besar (big bets), opsi (options), dan tindakan tanpa penyesalan (no regrets).

Big Bets, seperti namanya, merupakan keputusan strategis perusahaan untuk melakukan taruhan besar dalam situasi penuh ketidakpastian. Strategi ini diambil hanya oleh perusahaan yang dalam pengembangan skenarionya melihat alternatif-alternatif yang berlawanan secara ekstrim: untung besar vs rugi besar. Strategi ini juga hanya diambil oleh perusahaan yang memutuskan untuk menjadi shaper atau pembentuk industri di masa depan.

Pengembangan skenario pada situasi ketidakpastian tingkat 4 membutuhkan seni. Namun memilih skenario sebagai strategi ke depan sangat mengandalkan visi pimpinan perusahaan. Untuk bertaruh, melakukan investasi besar, demi membentuk masa depan yang diyakini akan memberikan keuntungan bagi perusahaan. Options dirancang untuk mengamankan hasil sebesar-besarnya dari skenario terbaik sambil meminimalkan kerugian dalam skenario terburuk. Sebagian besar opsi melibatkan investasi awal terbatas yang akan memungkinkan perusahaan untuk meningkatkan atau mengurangi investasi nanti ketika pasar berkembang. Contoh klasik termasuk melakukan uji coba sebelum pengenalan produk baru dalam skala penuh, mengadakan usaha patungan terbatas untuk distribusi untuk meminimalkan risiko masuk ke pasar baru, atau melisensikan teknologi alternatif jika terbukti lebih unggul dari teknologi saat ini.

Mereka yang memilih postur strategis reserve sangat bergantung pada strategi options, tetapi perusahaan yang memilih postur shaper juga menggunakannya, baik untuk membentuk pasar yang muncul tetapi tidak pasti sebagai penggerak awal atau untuk melindungi taruhan besar mereka. Akhirnya, No Regrets adalah keputusan strategis yang menetapkan akan memilih satu "skenario apapun yang akan membuahkan hasil apa pun yang terjadi." Eksekutif menyukai strategi no regrets yang lebih jelas seperti inisiatif yang bertujuan mengurangi biaya, mengumpulkan informasi tambahan, atau membangun keterampilan yang mungkin diperlukan. Jangan memandang sebelah mata pada strategi yang tampak seperti kurang strategis ini, karena dalam situasi ketidakpastian tinggi, keputusan strategis seperti berinvestasi dalam kapasitas terbatas dan membuat produk baru yang sedang laku di pasar bisa menjadi langkah yang tidak perlu disesali (no regrets).

Pademi Covid-19 yang belum dapat diprediksi kapan berakhir demikian juga dengan vaksin pencegahnya yang sampai saat ini belum berhasil ditemukan untuk diproduksi masal membuat situasi kondisi masa depan sangat sulit diprediksi. Ketidakpastian ini jika ditinjau dari tingkatan ketidakpastian masuk dalam tingkat 4 peran top eksekutif sangat dibutuhkan dalam menentukan kebijakan strategi kedepan apakah tetap bertahan pada strategi dan industri yang dijalaninya selama ini atau dengan berani mengambil keputusan untuk merubah haluan perusahaan dengan menerapkan strategi baru, bahkan juga memasuki industri yang bukan core bisnisnya saat ini. Berdasarkan data-data pertumbuhan kinerja per sektor industri selama kuartal pertama tahun 2020, menunjukkan banyak sektor industri yang mengalami minus pertumbuhan dan bahkan ada sektor industri yang mengalami penurunan laba bersih hingga jauh dibawah 
$100 \%$ namun disisi lain beberapa sektor industri mengalami peningkatan yang cukup signifikan terutama sektor-sektor industri yang sangat mendukung aktifitas dalam masa pademi virus covid-19 ini. Berikut data-data yang dapat dihimpun dari beberapa sumber literatur.

\begin{tabular}{|c|c|c|}
\hline \multicolumn{3}{|c|}{$\begin{array}{l}\text { Rata-Rata Pertumbuham Kinerja } \\
\text { Emitten Kuartal I-2020 Per Sektior }\end{array}$} \\
\hline Sektor & $\begin{array}{l}\text { Pertumbuhan } \\
\text { Pendapatan }\end{array}$ & $\begin{array}{l}\text { Pertumbuhan } \\
\text { laba bersih }\end{array}$ \\
\hline Agrikultur & $18,1 \%$ & $136.2 \%$ \\
\hline Kontruksi bangunan & $-2,2 \%$ & $-14,3 \%$ \\
\hline Properti dan terkait & $6,1 \%$ & $-12,9 \%$ \\
\hline Pembiayaan dan asuransi & $-4.1 \%$ & $5.0 \%$ \\
\hline Perbankan & $8.78 \%$ & $5,76 \%$ \\
\hline Telekomunikasi & $13,8 \%$ & $361,4 \%$ \\
\hline Tambang & $1,1 \%$ & $-32,3 \%$ \\
\hline Barang konsumsi dan farmasi & $4,6 \%$ & $13,3 \%$ \\
\hline Teknologi dan media & $4,4 \%$ & $-34,4 \%$ \\
\hline Otomotif dan alat berat & $-10,3 \%$ & $-25.4 \%$ \\
\hline Perdagangan & $77,3 \%$ & $44.5 \%$ \\
\hline Pariwisata dan perhotelan & $-8,0 \%$ & $-1.934,3 \%$ \\
\hline Transportasi & $2,0 \%$ & $-29,4 \%$ \\
\hline Rumahsakit & $8.7 \%$ & $8,6 \%$ \\
\hline Industri dasar dan kimia & $-6,1 \%$ & $-21.3 \%$ \\
\hline Aneka industri & $-26,5 \%$ & $-60,4 \%$ \\
\hline
\end{tabular}

Berdasarkan data-data tersebut diatas dapat terlihat bahwa sektor industri seperti telekomunikasi mengalami pertumbuhan pendapatan 13,8\%, agrikultur tumbuh $18,1 \%$ dan sektor perdagangan tumbuh $77,3 \%$ ini menunjukan selama pademi covid-19 dan pembatasan kegiatan sosial maka sektor-sektor yang mendukung aktifitas pembatasan sosial seperti telekomunikasi, agrikultur, perdagangan dan juga barang konsumsi dan farmasi mengalami pertumbuhan yang baik. Disisi lain banyak sektor mengalami penurunan yang tajam seperti sektor otomotif dan alat berat, sektor aneka industri, pariwisata dan perhotelan. Terlebih jika melihat pertumbuhan dari laba bersih yang didapat sektor-sektor yang mengalami penurunan pendapatan laba bersihnya juga turun tajam seperti yang dialami sektor perhotelan dan pariwisata yang mengalami penurunan hingga $-1.934,34 \%$.

Dengan ketidakpastian yang disebabkan oleh virus-covid-19 dan belum diketahui sampai kapan akan berakhir? Masih percaya dirikah para top eksekutif untuk menggeluti bisnisnya disatu industri saja?. Herry Markowitz salah satu pakar dalam manajemen investasi mengemukakan "don't put all your eggs in one basket" (jangan letakan telur yang anda miliki dalam satu keranjang, letakanlah pada lebih dari satu keranjang). Konsep Herry Markowitz ini menjelaskan bahwa jangan berinvestasi disatu bidang/industri saja tetapi berinvestasilah dibeberapa bidang/industri agar risiko yang anda akan alami tersebar dibeberapa bidang tidak hanya disatu jenis industri saja. Konsep teori ini dikenal dengan diversifikasi investasi yang telah begitu banyak memberikan inspirasi kepada para praktisi, birokrat maupun akademisi. Dengan melakukan diversifikasi investasi kita dapat menghindar dari kerugian yang lebih besar karena risiko tersebar dibeberapa bidang yang kita investasikan.

\section{SIMPULAN}

Pademi covid-19 yang melanda dunia merubah banyak tatanan kehidupan. Pembatasan kegiatan sosial menjadi salah satu cara untuk menekan dan mengurangi penyebarannya. Penyakit akibat virus covid-19 ini belum dapat diprediksi kapan akan berakhir dan sampai saat ini belum didapatkan vaksin yang tepat untuk mencegah dan mengobatinya, hal ini tentu menimbulkan ketidakpastian akan masa depan. Akibat dari pademi global virus covid-19 banyak sektor industri mangalami penurunan kinerja dan bahkan beberapa dapat dikatakan mati suri akibat virus tersebut. Penurunan kinerja perusahaan haruslah diantisipasi dengan baik oleh para pengangku kepentingan diperusahaan, terutama para pimpinan atau top eksekutifnya. 
Antisipasi dilakukan dengan cara meninjau ulang strategi yang dijalani selama ini dan memformulasikan kembali strategi untuk menghadapi tantangan kedepan yang penuh ketidakpastian. Ketidakpastian dapat dikelompokan dalam 4 tingkatan, mulai dari tingkat yang masih dapat diprediksi variabel-variabel yang mempengaruhinya sampai kepada tingkatan yang penuh ketidakpastian yakni tingkat 4. Berbagai strategi dapat diterapkan dan terdapat beberapa pilihan strategi seperti: integrasi kedepan, integrasi kebelakang, integerasi horizontal, peneterasi pasar, pengembangan pasar, pengembangan produk, diversifikasi terkait, diversifikasi tidak terkait, penciutan/pengurangan, divestasi, dan likuidasi.

Penurunan kinerja perusahaan khususnya bagi yang berkecimpung hanya disatu bisnis/industri saja tentu sangat tidak baik dan akan menyebabkan perusahaan lambat laun akan mati karena karena industri yang digelutinya selama ini tidak memiliki daya tarik lagi. Pertumbuhan positifnya tidak dapat diprediksi kapan akan balik kekondisi semula pasca covid19 karena virus ini pun belum diketahui juga sampai kapan akan berakhir. Kata-kata bijak yang keluar dari Herry Markowizt "don't put all your eggs in one basket", perlu menjadi pertimbangan. Dengan mendiversifikasi bisnis kita maka risiko yang mungkin akan kita alami akan tersebar kedalam beberapa bisnis yang kita masuki. Memasuki industri baru memang bukan tanpa risiko tetapi setidaknya risiko itu sendiri dapat disebar walaupun cost awal untuk investasinya tidaklah kecil. dalam situasi ketidakpastian tinggi, keputusan strategis seperti berinvestasi dalam kapasitas terbatas, membuat produk baru yang sedang laku di pasar atau memasuki industri baru bisa menjadi langkah yang tidak perlu disesali (no regrets)

\section{DAFTAR PUSTAKA}

Besanko, David., Dranove, David., Shanley Mark., \& Schaefer, Scott. (2010). Economics of Strategy (5th ed.). John Wiley \& Son (Asia) Pte Ltd.

Ferrell, O.C., Hirt, Geoffrey A., \& Ferrell, Linda. (2009). Business A Changing World (7th ed.). New York, NY: McGraw-Hill/Irwin.

Harto, Puji (2005). Kebijakan Diversifikasi Perusahaan dan Pengaruhnya Terhadap Kinerja: Studi Empiris Pada Perusahaan Publik Di Indonesia. Tesis Universitas Diponerogo, Abstract 297-307.

João Ferreira, Jens Mueller and Armando Papa (2018), "Strategic knowledge management: theory, practice and future challenges", JOURNAL OF KNOWLEDGE MANAGEMENT, (C) Emerald Publishing Limited, ISSN 1367-3270, DOI 10.1108/JKM07-2018-0461.

Maganjo Peter Muriuk dan Kavale Stanley (2015)," Determinants of Strategic Plan Implementation in Organizations: A Case Study of Chai Trading Company Limited", The International Journal Of Business \& Management (ISSN 2321 -8916) Volume 3, Issue 4, April 2015.

Ningky Sasanti Munir (2020) Merumuskan formulasi strategi korporasi dalam ketidakpastian masa depan, SWA Online

Olivier Furrer, J. Rajendran Pandian dan Howard Thomas (2007), "Corporate strategy and shareholder value during decline and turnaround", Management Decision Vol. 45 No. 3, 2007 pp. 372-392 q Emerald Group Publishing Limited 0025-1747 DOI $10.1108 / 00251740710745025$

Pasi Heikkurinen (2018), "Strategic corporate responsibility: a theory review and synthesis", Journal of Global Responsibility Vol. 9 No. 4, 2018 pp. 388-414 Emerald Publishing Limited 2041-2568 DOI 10.1108/JGR-06-2018-0020

Terry, Goerge R., \& Rue, Leslie W. (2009). Principles of Management. Dow Jones-Irwin.

Thompson, Arthur A, Jr., \& Strickland III,A.J. (1999). Strategic Management: Concepts and Cases (11th ed.). Singapore: McGraw-Hill/Irwin.

Thompson, Arthur A, Jr., Strickland III,A.J., \& Gamble, John E. (2010). Crafting and Executing Strategy (17th ed.). New York, NY: McGraw-Hill/Irwin. 
Vanessa Pires and Guilherme Trez (2017), "Corporate reputation A discussion on construct definition and measurement and its relation to performance", Revista de Gestão Vol. 25 No. 1, 2018 pp. 47-64 Emerald Publishing Limited 2177-8736 DOI 10.1108/REGE-112017-00 